\title{
The earliest origins and suppression of trade unionism in the Fiji Islands
}

\author{
Kevin Hince*
}

This paper examines the earliest example of trade union activity in Fiji canvassing both the origins and suppression. The style of colonial government, especially when the status quo is threatened, the relationship between commercial interests and colonial officials and government, and the extent to which colonial governments of the time were prepared to infringe on individual rights in pursuit of "law and order" and the exercise of "paternal rights", are examined within the context of the events surrounding the emergence and control of labour unrest.

\section{Introduction}

The old people of $\mathrm{Ba}$, Tavua and Vatukoula remember the name of Edward Sanday. He was not a native Fijian nor an indentured labourer like their ancestors, but they remember him and they, and their children, know his descendents. Edward Sanday was a European who took a Fijian girl as his wife and lived amongst the coastal swamps of Ba. The precise motives which lie behind the actions of Edward Sanday just prior to and during the months of October-November, 1916, cannot be clearly determined, but there is no doubt that he stirred the feelings of many people in north west Fiji. And there is no doubt about the reaction of the government of the colony. Tangible evidence of such reaction exists, inter alia, in the file intiated in government records by the Colonial Secretary's Office headed "The Fijian Wharf Labourers' Union". 1

This, and associated files and minute papers, record what appears to be the earliest attempt to form a labour union in the Fiji Islands. Many earlier examples of collective action associated with protestation and industrial unrest by labourers are detailed elsewhere, but the notion of "union" or "unionism" was not present. ${ }^{2}$ The earliest records of

1. CSO $8477 / 16$. Fiji Wharf Labourers' Union - Complaints of treatment accorded to:

In this and other citations the reference CSO $8477 / 16$ (for example) refers to: Colonial Secretary's Office (Fiji), Minute Paper followed by reference number and year. The minute papers were examined in files maintained in the Western Pacific Archives, Suva, Fiji. A list of CSO Minute Papers referred to in this paper is included in the list of references.

2. Gillion (1962), for example, refers to a march by 130 Indian labourers from Nausori to Suva in April 1887 to complain of being overworked and underpaid. The marchers had committed an offence under the Ordinance and were prosecuted. There is also reference to strikes by labourers in February, 1886 at Navuso (p. 83), May, 1886 and February, 1888 at Kornivia (pp. 83 and 88) and at Labasa in April, 1907 (p. 48) and in 1913 (p. 49). An earlier period (to 1903) at Labasa is described as one of, "... almost a state of civil war". (p. 115).

Gillion (1977) refers inter alia to strikes and riots by cane farmers and labourers in 1920 and 1921 , a strike by Indian labourers at the Public Works Department in Suva in 1920, and the role of the Indian Association of Fiji. Reference is also made to a formation of a Fiji Indian Labour Federation in October 1920.

* Professor of Industrial Relations and Director, Industrial Relations Centre, Victoria University of Wellington. 
the formation of unions in the colony are those of the European Civil Servants Association (1921), an organisation of European teachers at Methodist Mission Schools (1924) and the Suva Teachers' Union (1928). The earliest previously recorded attempts to organise manual workers occurred amongst sugar workers in the north-west during 1939; and these actions led to the formation of the Mazdur Sangh (1940) and culminated in the Chini Mazdur Sangh (Sugar Workers Union) as registered in 1944. Other early aspects of organised labour in Fiji relate to groupings of tenant farmers which emerged in the 1930's (the earliest was the Kisan Sangh) and coalesced in the various farmers' unions of the 1940 s and later.

The following sections of the paper deal with the personal characteristics of Edward Sanday, the events leading up to and during the attempts to form the "Union", the subsequent events (including the discussion of deportation of Sanday, the attempt to revoke the pension of Seteriki Nasoki, with whom Sanday lived for a period, and discussions of prospective legislative change), before finally seeking to assess events and actions in the light of the main themes.

\section{Edward Sanday (the man)}

Agitator, social reformer, radical, conservative, worthless loafer are each descriptions applied from time to time to Edward Sanday.

District Commissioner Scott, involved as the local government official at Lautoka, regarded Sanday as a dangerous agitator, and a worthless loafer, sponging off the credibility of ignorant natives. (CSO 8063/16,8477/16). However, this is but one view. Sanday did have a deep concern about the social conditions of the native population, including the living conditions, safety arrangements (and associated accident record) under which wharf labouring work was performed. He was also concerned about the abuse of authority, including the abuse of native custom to create conformity and obedience by native labour.

Sanday wrote with a very clear hand and possessed a firm command of the language, albeit using the stylised form so prevalent at the time: "I once more take impertinence upon myself to write ...". (CSO 8477/16).

Sanday sought to form a union, a "Fiji Wharf Labourers Union". He was a member of the Australian Workers' Union. However, he placed limits to his radicalism by refusing to accept the association with that "inexpressible I.W.W.", (CSO 8901/16) and by indicating that he would only assist the Fijians if they would, “... do things in a white man's way (i.e.) no angry or unpleasant conversations no talk about punching etc. as is their usual old Custom" (CSO 8477/16).

Personal characteristics of Sanday which are documented in the Colonial Office records suggest that he was born in Fiji of European parentage. Sanday was, in fact, born in 1884 in the lower Hawkesbury River region of New South Wales. He was christened Edwin, although sometimes called Edward. He joined his father, William Frederick Sanday in Fiji in 1900, and married a Fijian girl in 1908. He worked for the Colonial Sugar Refining Company (CSR) at Labasa and $\mathrm{Ba}$ (and had been discharged from the latter employment), had lived for some time in the Yasawas and was, in late 1916, living with his Fijian wife at the island of Nanuya in the mangroves near $\mathrm{Ba}$.

\section{Report of a strike by wharf labourers}

On 19 October, 1916, a telephone message was received at the office of the Colonial Secretary in Suva from the District Commission, Lautoka, referring to "trouble" among wharf labourers employed by CSR and the Union Steamship Company (USS) as a result of ". . . actions of a man Sanday". (CSO 8663/16). The report suggested that the wharf may be paralysed, that the labourers were forming a union and demanding 4 shillings for 
an 8 hour day (the then current rate was 3 shillings a day, 5 shillings night plus provisions for a 12 hour day). A letter from Sanday (dated 26 October, 1916) to the Governor amplified these complaints and demands as : unwholesome and insufficient food, dangerous working conditions, a request for a lean-to (shed), long tables and forms on the wharf as an eating place, and 4 shillings for 8 hours work.

The District Commissioner also asked for an examination of cables by Sanday from Lautoka to Sydney on 17 October, 1916. This request was then made to the acting superintendent telegraphs, and the text delivered to the colonial secretary. The relevant cable was addressed, "Secretary, Trades Hall, Goulburn Street, Sydney", and read "Have formed Fiji Wharf Labourers Union. Eight Hours. Can I receive recognition. Sanday."

On 21 October, $1916 \mathrm{Mr}$ Eva, manager of USS, after receiving a telephone report of a "strike of wharf labourers" loading sugar on the SS Kauri requested government permission to send 50 labourers from Suva to Lautoka on the government launch Ranadi (which was scheduled to travel there for other reasons). The Colonial Secretary advised the Governor that such permission be given, provided the USS Company agree to pay passage money. In such a way the government could, the Colonial Secretary advised, avoid the accusation of giving direct government assistance to employers of labour. The Colonial Secretary also advised that 6 constables under a non-commissioned officer be sent at the same time by that launch, as temporary reinforcements for the Lautoka police. The Governor agreed. The police on the Ranadi carried arms but no ammunition. Advice communicated to Inspector Stanlake of Lautoka was that the police should exercise care, that their foremost duty was to preserve peace and good order, but that upon ".... any glaring violation of the law the ringleaders should be arrested and the remainder dispersed" (CSO 8123/16). The Ranadi, with the aforementioned complement of passengers, departed Suva on the morning of 23 October.

At 2 p.m. on the same day the District Commissioner, Lautoka, advised the Colonial Secretary by telegram that the ship was working satisfactorily, and everything was quiet. With this assurance the Governor was advised that no immediate trouble was anticipated. And in respect of the actions set in train earlier in that week this advice is seen, in retrospect, to have been correct - no immediate trouble did eventuate.

That same day, 23 October, 1916, District Commissioner Scott wrote to the Colonial Secretary to, inter alia, place on record his complaints about Edward Sanday. Scott wrote that Sanday approached the SS Kauri when she arrived on the Saturday evening and a section of the Namoli men ${ }^{3}$ refused to work. Sanday, so Scott wrote, induced the men from Nadroga village to return to their village without working. Scott had, he states, advised the men to disregard Sanday, to let communal work stand for the time and to work the vessel. Given the text of the telegram sent by Scott it appears that at this time the advice of the District Commissioner was accepted; although herein, perhaps lies one basis for the accusation by Sanday of an abuse of native customs by the District Commissioner. Sanday detailed his perspective in the letter of 26 October, referred to earlier. The contents of this letter will also be discussed in more detail later.

\section{Official action and native custom}

A memorandum titled "Disaffection amongst the Polynesian and Fijian Labourers at Lautoka", dated 8 November 1916, was hand delivered from CSR to the Governor. The memorandum indicated that the company had been paying the "Polynesians" 2 shillings a day for the hours worked on the steamers, and that when no vessels were in port

3. Namoli, a village located in the environ of Lautoka. Note the reference later to Sanday staying with the ex-Buli of the Namoli village - Seteriki Nasoki. 
some were offered other work under similar conditions. ${ }^{4}$ The company also provided hut sites and paid the associated hut tax. Sanday had organised workers to demand 4 shillings per day, the company had offered 3 shillings but the men did not respond due to, the company asserted, Sanday's influence. The company had contemplated evicting the labourers from the huts because they were not working, but feared resistance.

Government response was to telegram the District Commissioner, Lautoka, to instruct him to offer his services to the manager of CSR, Lautoka, as a mediator with the "Polynesians", to seek to persuade them to return to work at the offer of 3 shillings per day, and to make reference to the threat of eviction. The District Commissioner confirmed that he would act accordingly, but the "Solomon Islanders" adhered to their demands.

In response to the telegram from the Colonial Secretary, the District Commissioner's offer of assistance was made, and accepted, by Mr Farquahar, Lautoka manager of CSR. The men had "scattered" so Scott sent a "tabua" (whale's tooth) by "mata" (messenger) to the headman of the Solomon Islanders, asking the headman to come to see Scott the following day. The Bilosi (headman) and 6 others came. Yagona was presented and Scott pointed out that it was best to work for 3 shillings a day ( $5 \mathrm{~s}-6 \mathrm{~d}$ a night), and referred to the threat of eviction. The Bilosi, according to Scott, was prepared to accept but stated a need to see his people.

Sanday, at this time, wrote to Scott asking the (rhetoric) question, “... why are you employing so much of the Government time trying to coerce Fijians .... to work for CSR Company 12 hours on the wharf ...", and complaining that it was not etiquette for a European to use the tabua (whale's tooth). (CSO 8802/16).

District Commissioner Scott, clearly took the charges laid by Sanday seriously and sought to defend his position. First, in response to a query as to whether Scott would be prejudiced if he had to act as a magistrate in cases against strikers, he responded that he would not be so influenced, and he did not believe it was necessary to assign another District Commissioner for such hearings.

Second, he attacked Sanday personally (worthless loafer, dangerous agitator, etc.), and argued the actions such as Sanday had taken were undermining the confidence of the natives in the administration and were detrimental to the general peace and good order.

\section{Reaction by a colonial bureaucracy}

Immediately the "trouble" began the possibility of deporting Sanday was considered, but when information received indicated that Sanday was Fiji born this course of action was abandoned. It is, of course, ironic, in retrospect, to ponder on this error of information.

Deportation is one of the operational tools utilised by a colonial government whereby a threatened disturbance to the status quo could be minimised. Invocation of existing legislative controls, the involvement of the police and discussion of legislative change were other such means involved in this particular case.

The possibility of using Ordinance 1 of 1875 was discussed in memoranda involving the Attorney General, Colonial Secretary and the Governor. Section 3 of that ordinance provided power for the Governor to act where he considered an individual, "... commits acts dangerous to the peace and good order of the colony". Section 5 enabled the Governor, in such circumstances, to prohibit a person residing in a particular district or districts.

4. Documentary evidence (CSO 8802/16) suggests that those referred to here as Polynesians were in fact Solomon Islanders - that is, of Melanesian background. Whether one can accept this as an honest interpretive mistake, carelessness, or lack of interest in racial characteristics by the government officials is an unanswered question. A suspicion of a "homogeneity of natives" viewpoint is, however, not dispelled. 
While Ordinance 1 of 1875 powers were not utilised in this instance, it was realised such powers were limited to the control of individuals (perhaps leaders), but not necessarily capable to controlling collective action. Hence discussion of potential legislative change.

In the latter context the Attorney General advised the Colonial Secretary that there were no provisions under existing law to deal with the type of labour "troubles" which had arisen on the waterfront at Lautoka. Under existing legislation it was necessary to wait until Sanday ("or his co-agitators"), threaten or intimidate others or cause a breach of the peace. And it was this advice which was carried to Lautoka by the non-commissioned police officer sent on board the Ranadi.

At this early stage the Attorney General suggested that after a full report of the facts consideration be given to introducing legislation to deal with any coalition of workmen. Early in November a meeting between the Governor Attorney General, Mr J M Hedstrom and $\mathrm{Mr}$ H M Scott (Eastern Division and Suva representatives on the Legislative Council respectively) discussed the desirability of legislation, “... to deal with persons agitating the coloured labour and thereby causing strikes" (CSO 8578/16). The Governor supported the notion. The Attorney General was asked to prepare a report, and his advice - that he knew of no legislation which renders it unlawful for a person to attempt to induce another to do what he is legally entitled to do, viz; refuse to work - further re-emphasised the legislative limitations at the time. There followed an examination of the applicability of the Master's and Servants Ordinance No. 2 of 1890 . The crux here was whether the labourers at Lautoka were under contract and hence could be constrained under that ordinance, where there was provision to deal with a servant who ceases to perform ordinary duties, and further potentiality of action against any person who caused or induced a servant to violate or attempt to violate any agreement of service. However, this ordinance, it was asserted, could not be applied for a month was the minimum period of a contract covered thereunder. And the terms of the labourers at Lautoka were of a more casual arrangement - the ship or ships.

Deportation, constraint, application of existing legislation and canvassing the possibility of legislative change were each part of the events in this case, and hence illustrate the operations of a colonial government in the face of "labour troubles". The examination of the possibility or revoking the pension of Seteriki, seems, however, to be action at a different level.

Seteriki Nasoki was a retired Buli of Namoli village. He was alleged to have given support, in lodgings and in encouraging native following, to Edward Sanday.

Sanday, had alleged that District Commissioner Scott dismissed Seteriki, “. . . from government service as the Turaga Ni Koro of Namoli because I was staying in his home,

if I (Sanday) came near his house to chase me away..." and threatened to write the Governor to cancel his (Seteriki's) pension. (CSO 8477/16). Seteriki confirmed this position.

The District Commissioner's view of events differed: he claimed he did not dismiss Seteriki for this occurred at a district council meeting, nor did he tell him the pension would be stopped, but had simply asserted that as Seteriki was receiving a government pension he should be loyal to the District Commissioner, and do as advised by him. Despite our general knowledge of the role and influence of District Commissioners at district council meetings, the matter outlined could be regarded as simply varying perceptions of a position. But not in this instance, for Scott had written to the Colonial Secretary on 3 November, 1916 asserting that Seteriki Nasoki was Sanday's strongest support and was doing his best to upset labour conditions despite Scott's warnings. Scott wrote further:

I submit that it would have a salutary effect if this man's pension was discontinued: he received his pension practically ex gratia on my recommendation to the Hon. the Secretary for Native Affairs. (CSO 8533/16). 


\section{Kevin Hince}

An investigation of the allegations, counter allegations, and of the issue raised in this letter was conducted by the Secretary of Native Affairs, and the Colonial Secretary, and the final advice which was accepted and acted upon was that Scott be advised that the complaints against him were "unfounded". Further, that Sanday be advised that the Governor was unable to view with favour any organisation among Fijians, that there were existing channels for handling complaints, and that the Governor believed that this was not the time for "fomenting dissatisfaction," "deprecate(d) any action which may lead to strikes and to disturbance", and that the action taken by Sanday was "... dangerous to the peace and order of the colony." (CSO 8477/16).

Later (8 December 1916) Seteriki was advised that his pension had been granted in the usual way, and there were not sufficient grounds to withdraw that pension.

\section{References to a 'union' or 'collective action'}

Associated with these events is the notion of a union. It remains, however, to highlight, to bring to centre stage, the union concept and to detail additional references to this conceptual base of the action and events of the time.

The name Fiji Wharf Labourers Union has been referred to; Sanday has been named as and has claimed to be the organiser, and he had made contact with the Australian trade union movement. Demands and threats were made in mid-October (and the Ranadi with labourers and police was sent to Lautoka), and further troubles (the withdrawal of labour by the Solomon Islanders and the intervention of the District Commissioner) occurred in early November.

Sanday registered (and appears to have been motivated by) concern with the condition of work on the wharf, in terms of both exploitation and safe working - "... Black Slavery ... carried on here at CSR Company's and USS Company's wharf", "... toiling 12 hours ... .", “. . . been several Fijian and Solomon boys killed or crippled for life". (CSO $8477 / 16)$.

Sanday asserted that Fijians at Namoli asked him about the principles and foundations of a union to defend British rights, and had begged him to be organiser. District Commissioner Scott's interpretation is quite different, but the attempt to organise and cause disruption of work tasks is common to both views.

Scott, for example, attested that Sanday approached the SS Kauri when she arrived and as a result a section of the Namoli villagers refused to work, and further, Sanday induced the whole of the Nadroga men to return to their village without offering for work. Scott asserted that Sanday was continuing to interfere with the native labourers, and that they were not used to this sort of conduct by a white man.

Sanday's allegations, and hence rationale for behaviour included that the Ba Fijians had given up working on the wharf because of unreasonable pay, heavy work and dangerous working conditions.

He wrote to the Governor detailing allegations of injuries which occurred during the loading of the SS Kauri and other vessels. The Governor ordered an inquiry into these allegations (and later was to castigate the Colonial Secretary for not replying promptly to Sanday's letter, and informing him that inquiries were being instituted).

Sanday had also expressed concern about the company paying the head man so much per head for men brought to the wharf:

especially in the Vuda and Sabeto and Nadroga Districts these head men do the Vaka Vanua Act (i.e.) call the men together and hand across some Kava and explain to them that the company has wrote to him for so many men and he would be greatly obliged to them if they would hop along. (CSO 8477/16).

Because of Fijian custom the men could not refuse. In fact, Sanday objected on 2 
grounds, the use of such an approach by a European, and that of sending a tabua and serving "grog" to Solomon Islanders. In the latter instance Sanday charged that Scott had used a Fijian custom which they (Solomon Islanders) do not recognise.

Associated with these allegations of an abuse of custom was further concern about the pressure placed on the men by the incumbent District Commissioner, who was, "... giving pretty stern orders to the Bulis".

Sanday also implies a complaint about a tactic used by the companies to keep labour for extended periods of need, viz;

... the USS Company has refused to pay labour for loading SS Kauri, they want them now to finish the SS Wanaka and then I suppose the Fiona..... (CSO 8477/16).

The reality or the unreality of the conditions of work, the validity or invalidity of positions at the time, need not be debated. It is clear that beliefs, either felt by the natives or articulated by Sanday, provided a basis for the actions. And disturbances and collective action occurred as a result.

The notion of a "union" subscription is implied in the context of a 10 shilling entrance fee payable to Sanday. His role as a "paid organiser" is implied in references to his followers giving him 4 shillings per week "... to endeavour to get their pay raised". (CSO $8477 / 16)$. Such monetary amounts were also a basis for allegations by District Commissioner Scott, that Sanday was "feathering his own nest".

The reaction to "unionisation" included sending additional labour, sending police reinforcements, examining the possibility of deporting or restricting the movement of leaders, awaiting the "false" move or "threat" or "intimidation" by leaders, the examination of all existing legislative controls, and the consideration of new legislation.

In the final context the recognition of a new dimension of labour problems - the union - is best illustrated by the communications between CSR management and government, and the meeting and discussions between Hedstrom, ${ }^{5}$ H M Scott, the Govenor and the Attorney General.

Before concluding this discussion, which has highlighted the concept of "union" within the totality of actions of the period, it is interesting, if not imperative, to mention 2 other items.

First, Sanday's membership of the AWU and his expressed horror at the possible association of his name with the IWW have been mentioned. In the same minute paper (dated 20 October 1916) in which the Colonial Secretary discusses Sanday's union membership there is a reference stating that:

Mr Eva mentioned to me (the Colonial Secretary) that there is a Mr McMillan in Suva who is supposed to be an agent for the Australian Worker's Union. . . (CSO 8063/16).

McMillan, however, whilst he was en route to Sydney, carried documents of US citizenship. Given such identification, the time period and Sanday's gratuitous reference, it is possible that McMillan was a representative or member of the IWW rather than the $\mathrm{AWU}$, and that his presence in Fiji is coincidental. Although the link is far too tenuous to suggest other than a need for further investigation, it is interesting to note the reference in Ian Turner's Sydney's Burning to a Tom McMillan organising for the IWW in Western Australia in 1914.

Second, in his letter of 11 November 1916, Sanday, inter alia, warns of trouble which might take place, ". . . if the head office of CSR company in Sydney does not abide by our reasonable demands". (CSO 8802/16). The lack of confidence in local management, the conviction that authority lay offshore was to be a continual feature of labour relations

5. Mr J M Hedstrom was associated with Morris Hedstrom and Company, at that time, and today, one of the larger trading companies operating in $\mathrm{Fiji}$. 


\title{
100 Kevin Hince
}

in the sugar industry, waterfront, and later other industries (oil, airlines, travel, etc.) in Fiji. Similar concern has also emerged in more sophisticated industrial relations systems where transnational corporations operate.

\section{Commercial interests and colonial government}

Reactions to the beginnings of labour troubles and union activity reflect the relationship between commercial interests and the colonial government, and the style and process of colonial government when under challenge.

Gillion assesses the relationship of the CSR company to the colonial government, in or about this period, in the following terms:

\begin{abstract}
... the role of the CSR company in the determination of the policy of the Fiji Government was undoubtedly an important role, although it was not as great as popularly believed in Fiji today to have been. It is true that the company was directly or indirectly responsible for a considerable proportion of the colony's revenues; that the Government tried, insofar as was consistent with other policies, to meet its wishes in regard to labour, land, communications and other matters; that on the local level there were many opportunities for the company's officers to influence government officials (intentionally or unintentionally): . . . Still the extent of the company's power should not be overestimated

The company was interested in its profits, not in running the colony, and was prepared to work within conditions laid down by the Government. The Government in its turn, recognising the important part played by the Company in the prosperity of Fiji, tried to meet its wishes unless these conflicted with the interest of the colony generally. (Gillion, 1962).
\end{abstract}

Government assistance in organising native labour for labouring duties, the despatch of police reinforcements, general concern over the actions of Sanday and the concept of unionism, and the close liaison of CSR officers with colonial officials, does not contradict the general thrust of Gillion's analysis. The degree and form of involvement do not demonstrate a superior and inferior partner in this relationship, and actions appear best interpreted in the light of this perspective.

Commercial interests and government shared a common interest in the preservation of law, order and the status quo. Action was in such joint interests, but one price was an interpretation or frame of reference recognising paternalism as the appropriate form of control of the native population. A further price involved the suppression of individualism and challenge, either individual or collective.

Despite conceding general agreement with Gillion, it can be argued that the actions and responses of District Commissioner Scott, at Lautoka, indicate that, at least at the local interface level, a more rigid, or perhaps righteous, acceptance of governing in the interests of commercial needs.

In 1916 the linkage between colonial officials and commercial operations in the administration of native affairs for a "common good" involved the suppression of "unionism" and associated actions. Later the thrust would change and postive encouragement to unionism would develop as the basis of colonial policy. (See Hince, 1971).

\section{References}

Gillion, K L (1962) Fiji's Indian Migrants Melbourne, Oxford University Press.

Gillion, K L (1977) The Fiii Indians Canberra, A.N.U. Press.

Hince, K W (1971) Trade Unionism in Fiji Journal of Industrial Relations 13: 368-389.

Turner, I (1967) Sydney's Burning London, Heinemann. 
Minute papers related to this paper held in the Western Pacific Archives, Suva, include:CSO 8063/16 Report threatened strike by wharf labourers.

CSO 8123/16 Strike amongst wharf labourers at Lautoka.

CSO 8199/16 Labour unrest in Lautoka.

CSO 8477/16 Fiji Wharf Labourer's Union - Complaints of treatment accorded to:

CSO 8533/16 Labour unrest in Lautoka - Report further on:

CSO 8578/16 Necessity of legislation - Person induced native labour not to work.

CSO 8901/16 (Untitled).

CSO 8312/16 Employment of wharf labourers at Lautoka.

CSO 9674/16 Seteriki Nasoki - pension. 